\title{
No Tolerance to Peripheral Morphine Analgesia in Presence of Opioid Expression in Inflamed Synovia
}

\author{
Christoph Stein, ${ }^{\star}$ Martina Pflüger, ${ }^{\ddagger}$ Alexander Yassouridis, $\|$ Jürgen Hoelzl, ${ }^{\S}$ Klaus Lehrberger, ${ }^{\star \star}$ Carmen Welte, ${ }^{\ddagger}$ \\ and Ahmed H.S. Hassan" \\ *Department of Anesthesiology and Critical Care Medicine, Johns Hopkins University, Baltimore, Maryland 21287-8711; Departments of \\ ${ }^{\ddagger}$ Anesthesiology and ${ }^{\S}$ Pathology, Ludwig-Maximilians-Universität, 81377 München; Departments of $\|_{\text {Biostatistics and }}$ \\ ${ }^{\mathbb{I}}$ Neuropharmacology, Max-Planck-Institut für Psychiatrie, 80804 München; and **Praxis und Belegkliniken für Spezielle Orthopädische \\ Chirurgie, 82008 Unterhaching, Germany
}

\begin{abstract}
Pain treatment with centrally acting opiates is limited by tolerance. Tolerance is a decreasing effect of a drug with prolonged administration of that drug or of a related (e.g., endogenous) compound acting at the same receptor. This is often associated with a downregulation of receptors. In peripheral inflamed tissue, both locally expressed opioid peptides and morphine can produce powerful analgesia mediated by similar populations of opioid receptors. We hypothesized that the chronic presence of endogenous opioids in inflamed joints might convey downregulation of peripheral opioid receptors and tolerance to the analgesic effects of intraarticular morphine. We assessed these effects after arthroscopic surgery in patients with and without histologically verified synovial cellular infiltration, and we examined synovial opioid peptides and opioid receptors by immunocytochemistry and autoradiography, respectively. We found that, despite an abundance of opioid-containing cells in pronounced synovitis, morphine is at least as effective as in patients without such cellular infiltrations, and there is no major downregulation of peripheral opioid receptors. Thus, opioids expressed in inflamed tissue do not produce tolerance to peripheral morphine analgesia. Tolerance may be less pronounced for peripherally than for centrally acting opioids, which provides a promising perspective for the treatment of chronic pain in arthritis and other inflammatory conditions. (J. Clin. Invest. 1996. 98:793799.) Key words: receptors, opioid • peptides, opioid • pain • arthritis • injections, intraarticular
\end{abstract}

\section{Introduction}

Opiate drugs are widely used in the clinical management of pain, but their usefulness is limited by tolerance and other central side effects (1). Tolerance is a decreased effect of a drug with prolonged administration of that drug or of a related compound acting at the same receptor (known as cross-tolerance) $(2,3)$. In

Address correspondence to Christoph Stein, M.D., Department of Anesthesiology, Johns Hopkins Hospital, Tower 711, Baltimore, MD 21287-8711. Phone: 410-614-1516; FAX: 410-955-0994; E-mail: CSTEIN@ gwgate1.jhmi.jhu.edu

Received for publication 5 March 1996 and accepted in revised form 28 May 1996.

J. Clin. Invest.

(C) The American Society for Clinical Investigation, Inc.

0021-9738/96/08/0793/07 \$2.00

Volume 98, Number 3, August 1996, 793-799 the central nervous system (CNS), ${ }^{1}$ tolerance develops to exogenous and to endogenous opioids $(4,5)$; it is often associated with a decrease in the number of opioid receptors (downregulation) (2), and cross-tolerance to exogenous agonists can occur after the chronic activation of receptors by endogenous ligands $(6,7)$.

Opioid analgesia is not exclusively mediated within the CNS, however. Locally applied opioids have antinociceptive and antiinflammatory actions in inflamed tissue of animals (reviewed in references 8,9 ); intraarticular (i.a.) morphine produces potent clinical analgesia after surgery of the knee joint (reviewed in reference 10) and these effects are mediated by opioid receptors outside the CNS. Animal experiments have shown that such peripheral opioid receptors are localized on sensory nerve terminals $(11,12)$ and that these receptors can be activated by exogenous mu-, delta-, and kappa-opioid agonists $(8,9)$ as well as by endogenous opioid peptides expressed in inflammatory cells $(11,13)$. These peptides can be released (14) and produce powerful tonic inhibition of clinical pain (15) with a potency similar to that of i.a. morphine (16). Moreover, both of these effects are reversible by comparable doses of the opioid antagonist naloxone $(15,16)$, suggesting that morphine and the endogenous peptides act on similar populations of peripheral opioid receptors.

In the present studies we hypothesized that the chronic presence of opioid-containing cells in inflamed joints might convey downregulation of peripheral opioid receptors and tolerance to the analgesic effects of i.a. morphine. Therefore, we assessed these effects after arthroscopic surgery in patients with and without histologically verified cellular infiltration of the synovia, and we examined synovial opioid peptides and opioid receptors by immunocytochemistry and autoradiography, respectively.

\section{Methods}

Patients. The study protocol adhered to the ethical guidelines of the International Association for the Study of Pain (17); it was approved by our institutional ethical committee and written informed consent was obtained from each patient. We examined 42 inpatients undergoing arthroscopic knee operations. These were carried out by the same surgeon and included partial meniscectomies, synovectomies, chondrectomies, arthrophyte extractions, and removal of crystalloid deposits, with approximately equal representation among the groups. The criteria for exclusion from the study were evidence of severe cardiovascular, respiratory, metabolic or neurologic disease and the requirement for postoperative intraarticular drainage. All patients were premedicated with clorazepate dipotassium $(0.3 \mathrm{mg} / \mathrm{kg}$ per os $) 2 \mathrm{~h}$ be-

1. Abbreviations used in this paper: CNS, central nervous system; i.a., intraarticular; i.v., intravenous. 
fore surgery. Anesthesia was induced with intravenous (i.v.) vecuronium $(2 \mathrm{mg})$, methohexital sodium $(1.5 \mathrm{mg} / \mathrm{kg})$, and succinylcholine $(1 \mathrm{mg} / \mathrm{kg})$ and maintained with oxygen/nitrous oxide and enflurane with supplemental doses of vecuronium as needed. No opioids were administered intraoperatively.

Study protocol. At the end of surgery, before the arthroscope was removed, the following substances were administered simultaneously in a randomized, double-blind manner: 23 patients received i.a. morphine hydrochloride (E. Merck, Darmstadt, Germany) (1 mg in $40 \mathrm{ml}$ normal saline) and i.v. saline $(1 \mathrm{ml})$. As a control for the systemic absorption of morphine, 19 patients received i.a. saline $(40 \mathrm{ml})$ and i.v. morphine (1 $\mathrm{mg}$ in $1 \mathrm{ml}$ saline). These doses were chosen on the basis of our previous studies in humans (16). The solutions were drawn into coded syringes by a nurse and given to the anesthesiologist and surgeon, respectively, who did not know their contents and performed the injections. General anesthesia was then terminated. The codes were broken at the end of the study.

Assessment of pain. Postoperative pain was assessed using a 100-mm visual analogue scale ranging from no pain $(0 \mathrm{~mm})$ to unbearable pain $(100 \mathrm{~mm})$, a numerical rating scale ranging from 0 to 100 , and a German adaptation of the McGill Pain Questionnaire $(18,19)$. The use of these pain measures was explained to each patient before surgery. The scores were taken by the same investigator 1, 2, 3, 4, 6, and $24 \mathrm{~h}$ after the injection of the drugs. Supplemental analgesic medication (intramuscular diclofenac and meperidine) was available to all patients at all times, and its consumption was recorded hourly.

Assessment of vital signs and side effects. Blood pressure, heart rate, respiratory rate, somnolence score, and side effects were recorded at the above intervals. Somnolence was assessed using a five point scale ranging from "awake and oriented" to "not arousable." The side effects monitored included pruritus, nausea, urinary retention, and rash.

Histology. Synovial specimens were obtained during surgery as part of a routine pathological assessment of the prevalence and severity of synovial inflammation. The tissue was fixed in formalin, dehydrated in ethanol, embedded in paraffin, and stained by hemalum-eosin. A blinded observer assessed the presence and abundance of inflammatory cells, of follicular infiltrates, and the proliferation of synovial lining cells. The patients were then categorized into those with none or minimal presence ("negative") $(n=25)$ and those with marked prominence ("positive") of the above signs $(n=17)$ (Fig. 1). This classification was unrelated to the duration of the patient's disease (Table I) and yielded the following: group 1 (i.v. morphine, negative; $n=11$ ), group 2 (i.v. morphine, positive; $n=8$ ), group 3 (i.a. morphine, negative; $n=14$ ), group 4 (i.a. morphine, positive; $n=9$ ). These groups were not significantly different with regard to demographics, duration of history, vital signs and duration of surgery (Table I).

Immunocytochemistry. Due to the limited amount of tissue obtained from each trial patient, synovial specimens from 10 separate patients who underwent similar operations were examined. According to the criteria mentioned above, 6 patients had inflamed and 4 had noninflamed synovia. The tissue was fixed in Zamboni's fixative for $4-6 \mathrm{~h}$ at $21^{\circ} \mathrm{C}$ and washed overnight at $4^{\circ} \mathrm{C}$ in PBS $(0.05 \mathrm{M}, \mathrm{pH}$ 7.3). The specimens were dehydrated in graded series of ethanol, cleared in methyl salicylate, and embedded in Paraplast Plus (E. Merck). Sections (5-7 $\mu \mathrm{m}$ thick) were cut, dewaxed in xylene, rehydrated in graded series of ethanol, washed briefly in PBS, and then immunostained using avidin-biotin peroxidase complex (Vector Laboratories, Burlingame, CA). Unless otherwise stated, all incubations were made at room temperature, and PBS was used for washing after each step. Endogenous peroxidase was quenched with $0.3 \% \mathrm{H}_{2} \mathrm{O}_{2}$ in PBS for $30 \mathrm{~min}$. Slides were washed twice $(2 \times 10 \mathrm{~min})$, incubated in $0.2 \%$ Triton $\mathrm{X}-100$ for $20 \mathrm{~min}$, washed twice $(2 \times 10 \mathrm{~min})$, incubated with normal goat serum (Vector Laboratories) for $30 \mathrm{~min}$, blotted (without washing), and overlayed with polyclonal rabbit antisera against $\beta$-endorphin-(1-31) (dilution 1:1,000), dynorphin-(1-17) $(5 \mu \mathrm{g} \mathrm{IgG} / \mathrm{ml})$ and met-enkephalin $(1: 1,000)$ (Peninsula Laboratories, Merseyside, UK) (for cross-reactivities, see reference 20) at $4^{\circ} \mathrm{C}$ overnight. Thereafter they were incubated with the biotinylated secondary antibody (Vector Laboratories) for $30 \mathrm{~min}$ and subsequently with avidin-biotinconjugated peroxidase (Vector Laboratories) for 30-45 min. Finally, the slides were stained with $3^{\prime}-3^{\prime}$ - diaminobenzidine tetrahydrochloride $(0.0125 \%)$ (Sigma Chemical Co., St. Louis, MO) including

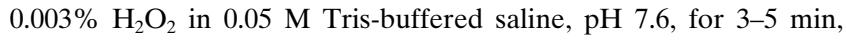
counterstained with nuclear fast red, and then dehydrated and mounted. To demonstrate specificity of staining, the following controls were included: $(a)$ preadsorption of the primary antisera with excess of homologous antigen $(1 \mu \mathrm{M} \beta$-endorphin, $10 \mathrm{nM}$ metenkephalin, $10 \mathrm{nM}$ dynorphin) for $24 \mathrm{~h}$ at $4^{\circ} \mathrm{C} ;(b)$ omission of either the primary antiserum, the secondary antibody or the avidin-biotinperoxidase complex.

Receptor autoradiography. Due to the limited amount of tissue obtained from each trial patient, synovial specimens (5 inflamed, 5 noninflamed) from separate patients who underwent similar operations were examined. The tissue was immediately frozen on dry ice and stored at $-80^{\circ} \mathrm{C}$. Cryosections $(20 \mu \mathrm{m})$ were cut at $-20^{\circ} \mathrm{C}$ and thaw-mounted onto glass slides which were serially precoated with $0.4 \%$ BSA and $0.05 \%$ poly-L-lysine. The sections were dried overnight at $4^{\circ} \mathrm{C}$ under reduced pressure in a glass desiccator containing silica gel and then stored at $-80^{\circ} \mathrm{C}$. Optimum binding conditions were determined in preliminary experiments including variations of preincubation time, concentration of the radioligand, incubation time and temperature, washing, and buffer composition. The slide-mounted frozen sections were gradually brought up to room temperature and preincubated for $15 \mathrm{~min}$ in $50 \mathrm{mM}$ Tris buffer, $\mathrm{pH}$ 7.6, containing 50 $\mathrm{mM} \mathrm{GTP}$ and $100 \mathrm{mM} \mathrm{NaCl}$ to dissociate endogenous ligands. This was followed by a 5 min wash in Tris buffer containing $0.2 \%$ BSA. The washed sections were transferred to a humidified container and covered with $0.1 \mathrm{ml}$ incubation buffer. This consisted of $50 \mathrm{mM}$ Tris buffer with $50 \mu \mathrm{g} / \mathrm{ml}$ bacitracin, $10 \mu \mathrm{g} / \mathrm{ml}$ leupeptin, $10 \mu \mathrm{g} / \mathrm{ml}$ soybean trypsin inhibitor (Sigma), and $2 \mathrm{nM}$ human $\left[{ }^{125} \mathrm{I}\right] \mathrm{Tyr}^{27}-\beta$-endorphin(1-31) (Amersham Corp., Arlington Heights, IL) (diluted to $500 \mathrm{Ci} /$ mmol with unlabeled $\beta$-endorphin). Nonspecific binding was determined in serial sections using $5 \mu \mathrm{M} \beta$-endorphin (Peninsula) as a dis-

Table I. Patient Characteristics

\begin{tabular}{|c|c|c|c|c|}
\hline Group & i.v. negative & i.v. positive & i.a. negative & i.a. positive \\
\hline $\operatorname{Sex}(f / m)$ & $2 / 9$ & $6 / 2$ & $7 / 7$ & $4 / 5$ \\
\hline Age (yr) & $44 \pm 5(21-65)$ & $58 \pm 5(37-80)$ & $56 \pm 3(28-70)$ & $53 \pm 7(17-64)$ \\
\hline Height $(\mathrm{cm})$ & $176 \pm 3(157-188)$ & $168 \pm 3(156-181)$ & $168 \pm 2(154-180)$ & $172 \pm 4(160-187)$ \\
\hline Weight $(\mathrm{kg})$ & $87 \pm 4(73-126)$ & $75 \pm 7(58-110)$ & $83 \pm 3(64-105)$ & $80 \pm 2(68-83)$ \\
\hline Duration of surgery (min) & $26 \pm 6(15-30)$ & $36 \pm 9(15-75)$ & $25 \pm 7(15-40)$ & $38 \pm 6(20-55)$ \\
\hline Duration of history (mo) & $41 \pm 25(1-240)$ & $43 \pm 14(1-120)$ & $48 \pm 18(1-180)$ & $33 \pm 20(2-192)$ \\
\hline
\end{tabular}

Subjects with (positive) or without (negative) cellular infiltration of the synovia received intravenous (i.v.) or intraarticular (i.a.) morphine. Values are means \pm SEM and ranges are given in parantheses. 

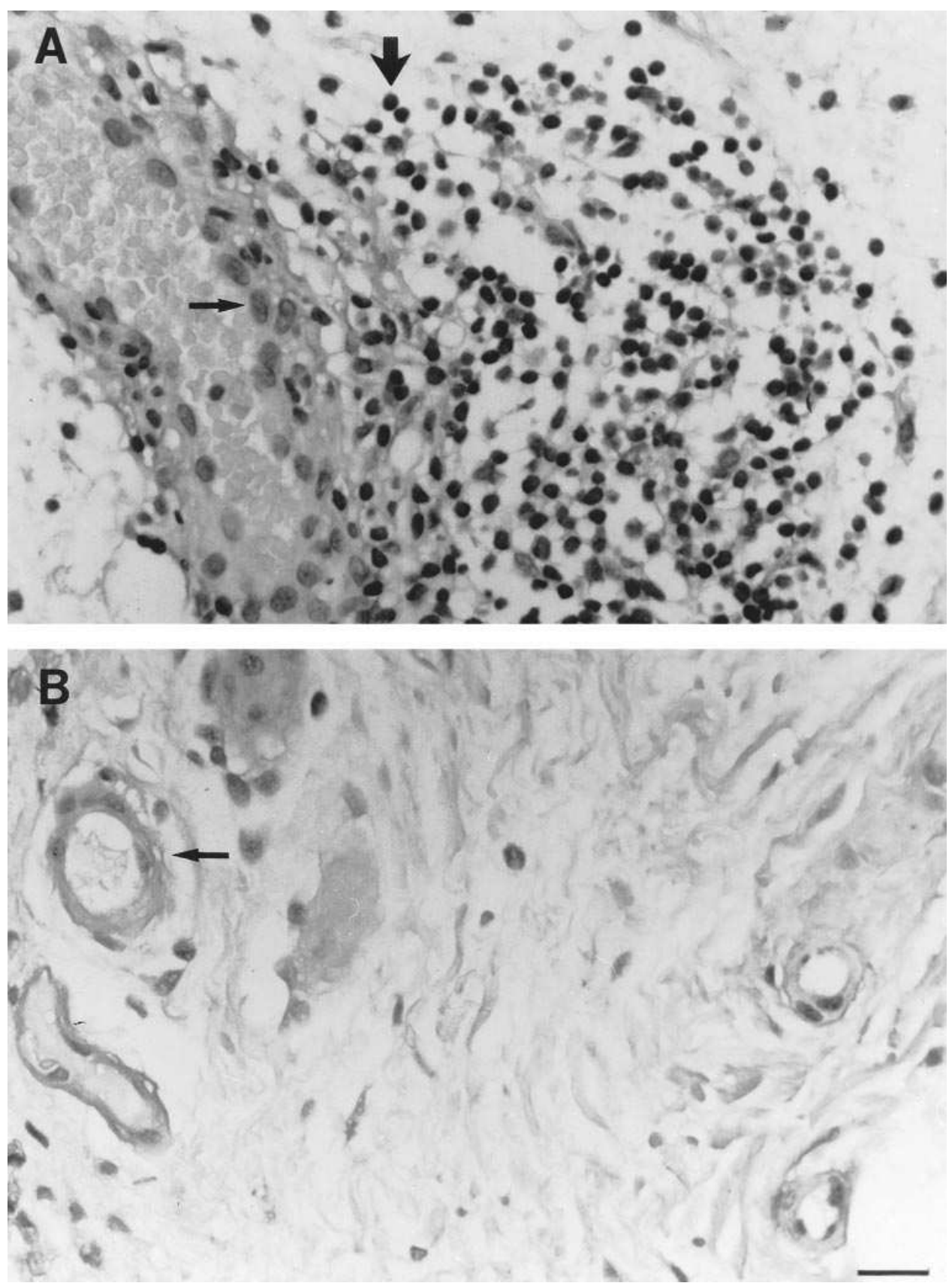

Figure 1. Synovial tissue sections of patients with $(A)$ and without $(B)$ cellular infiltration, stained with hemalum-eosin. A dense follicular infiltrate (large arrow, $A$ ) of mononuclear inflammatory cells (mainly lymphocytes and some plasma cells) is seen in the immediate vicinity of a sinusoid (small arrow, $A$ ). The synovial stroma in $(B)$ contains capillaries (arrow, $B$ ) and fibroblasts but no cellular infiltrates. Scale bar $=$ $20 \mu \mathrm{m}$.

placer. The sections were incubated for $1 \mathrm{~h}$ at room temperature, followed by four consecutive washes (1 min each) in $400 \mathrm{ml}$ ice-cold 50 $\mathrm{mM}$ Tris buffer with $0.2 \%$ BSA and a final rinse in ice-cold distilled water to remove slates. They were then dried under a stream of cold air.

For light microscopic autoradiography the slide-mounted sections were exposed to paraformaldehyde vapors at $80^{\circ} \mathrm{C}$ for $2 \mathrm{~h}$ to fix and maintain the ligand-receptor complexes. They were individually dipped into LM-1 photo emulsion (Amersham) and exposed for $7 \mathrm{~d}$ at $4^{\circ} \mathrm{C}$. They were then developed in Kodak D-19 (Eastman Kodak Co., Rochester, NY) (4 min at $18^{\circ} \mathrm{C}$ ), fixed in Kodak Rapid Fix (10 min at $18^{\circ} \mathrm{C}$ ), counterstained with Giemsa, and examined under bright-field illumination using a Leitz Vario Orthomate microscope. Previous saturation and competition studies had shown that the pharmacological characteristics of the binding sites labeled under these conditions are consistent with those of mu- and delta-opioid receptors in the CNS (12).

Data analysis. Demographic data and vital signs measured on interval scales were analyzed by one-way multivariate analysis of vari- ance (MANOVA) with "group" as the between subjects factor. For variables measured on nominal scales (somnolence score, occurrence of side effects, gender) the chi-square analysis was applied to compare frequency distributions among the groups (21). To score the visual analogue scale, the distance (in $\mathrm{mm}$ ) from the "no pain" end to the mark provided by the patient was measured. To score the McGill Pain Questionnaire, the pain rating indices based on the patient's mean scale values were calculated for each category (sensory, affective, evaluative, miscellaneous) and for all categories (total), and the number of words describing pain were counted, according to Melzack (22). To determine supplemental analgesic requirements, the total consumption of each agent per $24 \mathrm{~h}$ was recorded for each patient. Group differences in the pain scores and analgesic requirements were tested by MANOVA with repeated measures design. In case of significant differences the contributing variables were identified with F-tests and pairwise post-hoc comparisons between groups were made by tests of simple effects (contrasts). Additionally, the areas un- 

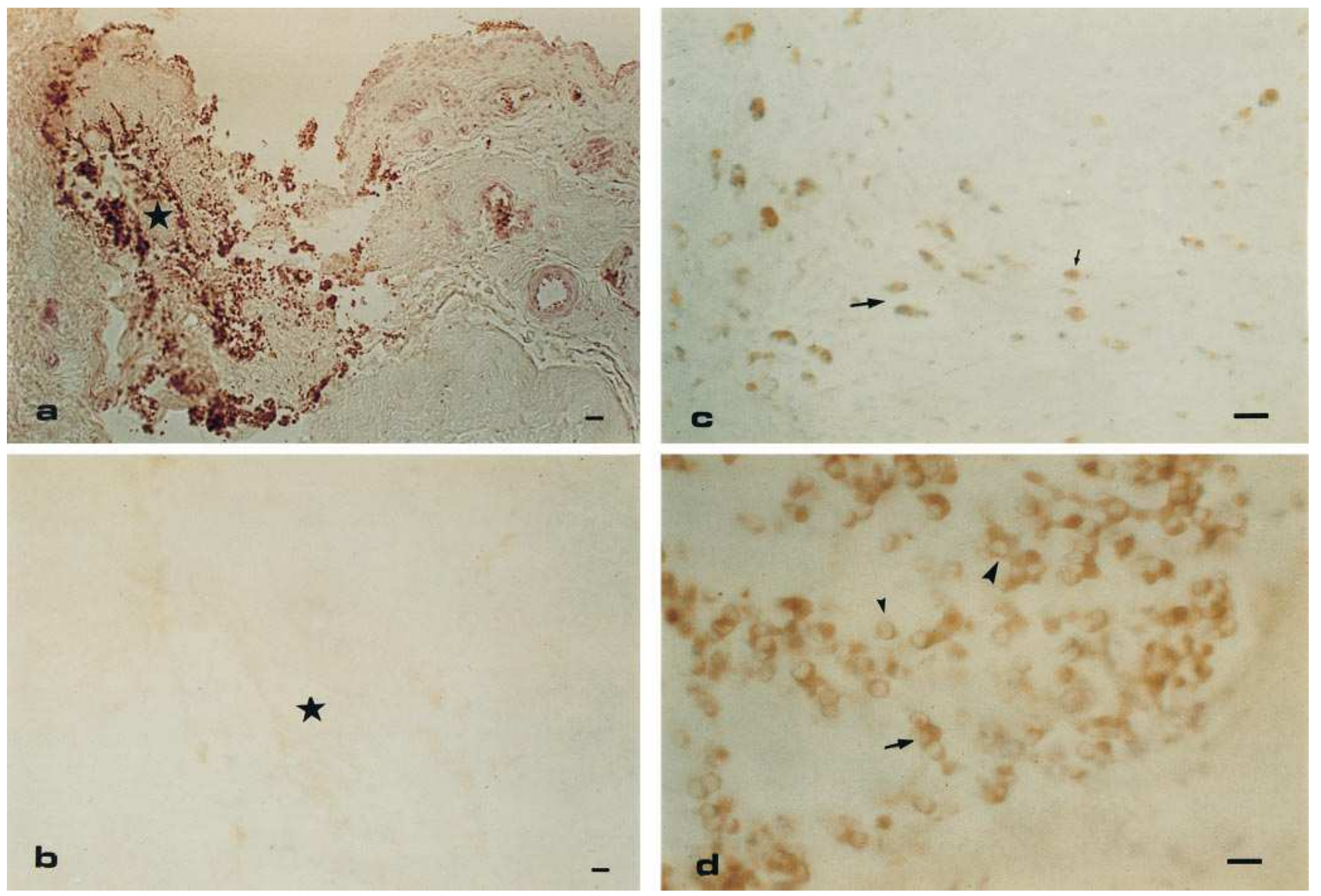

Figure 2. Immunostaining of $\beta$-endorphin in the synovia of a patient with prominent cellular infiltration. A representative example of typical findings is shown. (a) Intense immunoreactivity is seen in the inflammatory follicles (brown deposits, star). (b) After preadsorption of anti$\beta$-endorphin with $\beta$-endorphin, the immunoreactivity is completely extinguished in a section adjacent to $a$. (c) Immunoreactivity in mast cells (large arrow) and lymphocytes (small arrow) infiltrating the synovial intima. (d) Higher magnification: immunoreactive cells appear as macrophages (large arrow head), lymphocytes (small arrow head), and synoviocytes (arrow) (scale bars $=15 \mu \mathrm{m})$. Staining with anti-met-enkephalin and antidynorphin yielded similar results (not shown). Noninflamed synovia did not stain with any opioid antiserum (not shown).

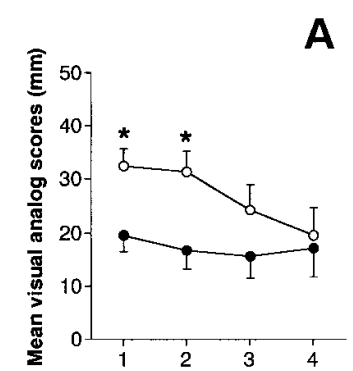

A
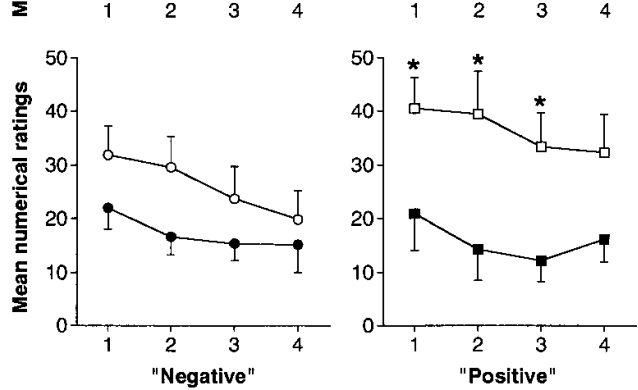

Hours after morphine injection

B

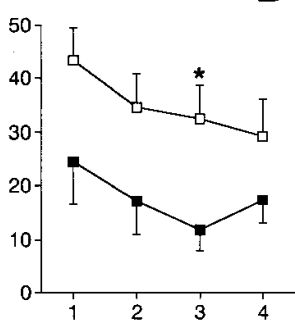

के
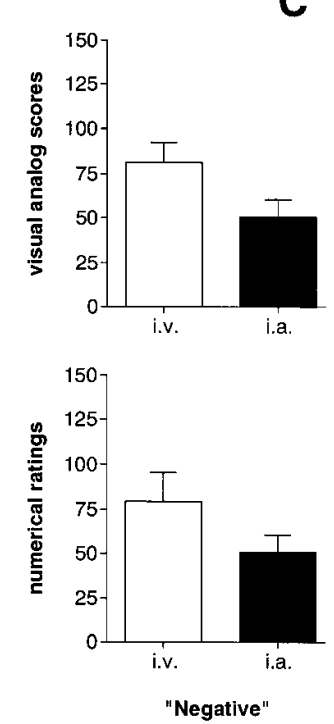

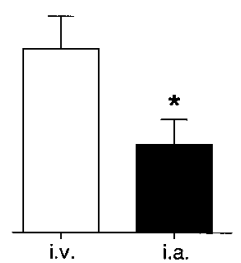

i.a.

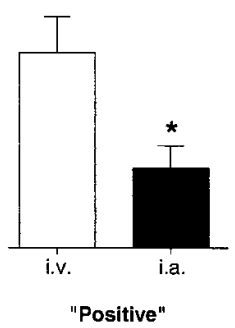

Figure 3. Postoperative pain scores of patients without ( $A$ and $C$; negative) and with ( $B$ and $D$; positive) synovial cellular infiltration. $\mathrm{Pa}-$ tients received $1 \mathrm{mg}$ of morphine i.v. (open symbols) or i.a. (solid symbols). $C$ and $D$ show areas under the curves of visual analogue (top) and of numerical pain rating scores (bottom). Values are means \pm SEM.

*Significant differences $(P<0.05$;

Duncan's test) between groups. No differences were observed at 6 and $24 \mathrm{~h}$ (not shown) or between males and females. Parallel trends of data were obtained by the McGill Pain Questionnaire and the supplemental analgesic consumption (not shown). 


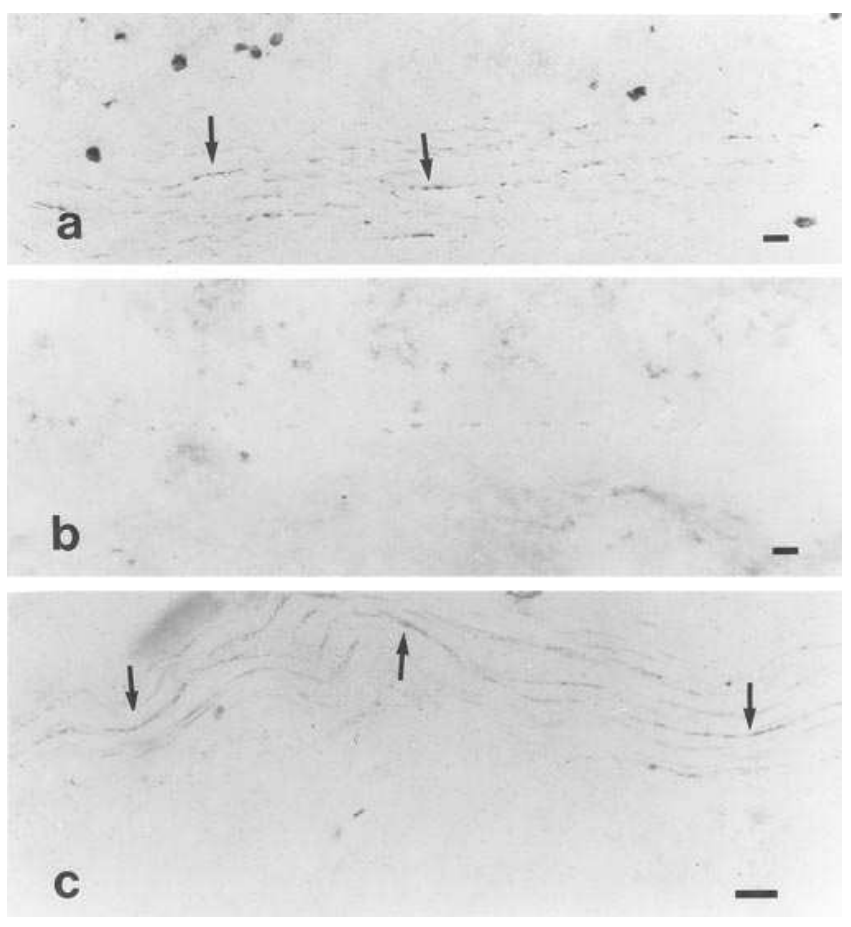

Figure 4. Autoradiographs of $\left[{ }^{125} \mathrm{I}\right] \beta$-endorphin binding in synovial tissue. Representative examples of typical findings are shown. Sections are from inflamed ( $a$ and $b$ ) and noninflamed $(c)$ tissue. The binding is completely displaced by $5 \mu \mathrm{M}$ unlabeled $\beta$-endorphin $(b)$. The density of grains on individual nerve fibers (arrows) appears similar in inflamed (a) and noninflamed (c) synovia. Scale bars $=10 \mu \mathrm{m}$.

der the curves of the pain scores between 1 and $4 \mathrm{~h}$ were calculated according to the trapezoid rule and analyzed by one-way MANOVA and Duncan's test. Results are given as means and SEM. A level of significance equal to or $<0.05$ was accepted and was corrected by the Bonferroni procedure when multiple post-hoc tests or tests of contrasts were performed.

\section{Results}

All patients were awake and oriented throughout the observation period and did not report any major side effects. Control subjects receiving i.a. morphine (groups 3 and 4 combined) had significantly lower pain scores than patients receiving i.v. morphine (groups 1 and 2 combined) up to $4 \mathrm{~h}$ after surgery $(P<$ $0.05, t$ test for contrasts; data not shown). This is consistent with previous reports (reviewed in reference 10) and demonstrates that i.a. morphine provides effective postoperative analgesia by a peripheral mechanism of action.

Our histological analysis yielded subgroups without (groups 1 and 3, "negative") and with marked cellular infiltration of the synovia (groups 2 and 4, "positive") (Fig. 1). The immunocytochemical studies showed that $\beta$-endorphin, metenkephalin, and dynorphin were detectable within inflamed but absent in noninflamed tissue (Fig. 2). In both of these subgroups, patients receiving i.a. morphine also had significantly lower pain scores than those receiving i.v. morphine. This difference was even more pronounced in patients with (Fig. $3 B$ and $D$ ) than in those without marked cellular infiltrates (Fig. $3 \mathrm{~A}$ and $C$ ).
The receptor autoradiography revealed that opioid binding sites were mainly associated with small diameter nerves in the subepithelial interstitial tissue. Some of these nerves reached the epithelial layer. The autoradiographic grains were arranged in distinct longitudinal streaks running parallel to the nerve fibers (Fig. $4 a$ and $c$ ). Some grains were seen on inflammatory cells (Fig. $4 a$ ). The binding was specific since it was completely displaced by unlabeled $\beta$-endorphin (Fig. $4 \mathrm{~b}$ ). There were no major differences in the abundance and distribution of labeled nerves or in the density of labeling on individual nerves between noninflamed and inflamed synovial specimens (Fig. $4 a$ and $c$ ).

\section{Discussion}

This study shows that i.a. morphine elicits potent local analgesia both in patients with and without synovial cellular infiltration and that this effect may be even stronger in the former. Since these inflammatory cells contain opioid peptides and since opioid receptors are apparently not downregulated in inflamed synovia, these findings suggest the intriguing possibility that the continuous presence of immune cell-derived opioid peptides does not result in tolerance, but may even be associated with augmented exogenous agonist effects at peripheral opioid receptors.

This result is unexpected in view of the following facts: First, synovial opioid peptides are apparently present in sufficient concentrations to produce a tonic analgesic effect of similar magnitude as that elicited by i.a. morphine $(15,16)$. Second, both of these effects are reversible by comparable doses of the opioid antagonist naloxone $(15,16)$. Together, these observations suggest that i.a. morphine and the endogenous peptides act on similar populations of peripheral opioid receptors. Third, the duration of our patients' knee lesions (see Table I) strongly suggests that opioid peptide-producing inflammatory cells have been present for a long period of time. Thus, in spite of the plausible tonic activation of these receptors by immune cell-derived opioids, there is no tolerance to morphine. These findings are in contrast to central opioid analgesic actions, which are distinctly prone to the development of tolerance, i.e., a rapid decrease of efficacy with prolonged exposure to exogenous or to elevated levels of endogenous agonists $(2,4-7)$. Moreover, studies in the CNS indicate that even small amounts of endogenous opioids that do not produce analgesia are sufficient to produce tolerance $(4,5)$. Thus, in contrast to the situation in the CNS, the unique environment in peripheral inflamed tissue apparently counteracts the development of tolerance.

Proposed mechanisms of opioid tolerance include downregulation of receptors (23), uncoupling of receptors from G-proteins $(23,24)$, inactivation of G-proteins $(25,26)$, and increased activity of neuronal adenylate cyclase $(27,28)$. These mechanisms may be offset in the present situation because: $(a)$ there appears to be no major downregulation of opioid binding sites on nerve fibers in inflamed synovia (Fig. 4); (b) animal experiments have shown that inflammation upregulates peripheral opioid receptors $(12,29,30)$; $(c)$ inflamed tissue is characterized by a decreased $\mathrm{pH}$, and it has been shown that an acidic environment increases opioid binding to neuronal membranes, decreases the inactivation rate of receptor-coupled G-proteins, attenuates stimulated adenylate cyclase activity, and potentiates opioid receptor-mediated inhibition of adenylate cyclase 
$(31,32) ;(d)$ dynorphin, in this case derived from inflammatory cells, might increase the sensitivity of opioid receptors to exogenous agonists (33). Together, these factors could counteract the development of tolerance.

Two other observations are noteworthy: In central opioid and other G-protein-coupled receptor systems, an upregulation of endogenous ligands is typically paralleled by a downregulation of receptors $(34,35)$. This is clearly not the case in the present situation since the accumulation of opioid-containing immune cells in severe arthritis is associated with a pronounced analgesic efficacy of i.a. morphine and no apparent downregulation of neuronal opioid receptors. Second, analgesic effects of i.a. morphine are readily detectable in patients without marked cellular infiltration (Fig. $3 A$ ). This is consistent with experimental findings that peripheral opioid analgesia can be elicited in noninflamed tissue (36) and that relatively high basal levels of mRNA for opioid receptors are detectable in dorsal root ganglia (30), indicating that opioid receptors are continuously synthesized and present on peripheral sensory nerve terminals under normal conditions $(11,12)$. The functional efficacy of these preexistent receptors may depend on parameters such as accessibility (36) and ionic environment $(31,32)$, but the presence of endogenous ligands is apparently not essential.

In summary, instead of producing tolerance, the accumulation of immune cells containing and releasing opioid peptides in inflamed tissue is associated with powerful exogenous agonist effects, and there is no major downregulation of opioid receptors. This is probably due to the unique environment in inflammation. Thus, the severity of an inflammatory process is apparently not a limiting but a permissive factor for the treatment with peripherally acting opioid analgesics. Since currently available nonsteroidal and steroidal antiinflammatory drugs have serious side effects such as gastrointestinal bleeding, ulcer formation, hypersensitivity reactions, and kidney and liver damage, peripherally selective opioid compounds may provide a much sought after alternative for the management of chronic arthritic and other inflammatory conditions.

\section{Acknowledgments}

We thank Dr. Strahl-Hermann for making tissue sections available for histological analysis, Dr. A. Ableitner for expert advice with the autoradiography, Drs. S. Izenwasser, M. Schäfer and B. Simon for critical comments on the manuscript, and Mrs. Nita Taylor for secretarial assistance.

This work was supported in part by National Institutes of Health/ NINDS grant RO1NS32466 and IARS.

\section{References}

1. Fields, H.L., B.M. Cox, K.M. Foley, A.F. Haase, A. Herz, T. Hummel, M.J. Iadarola, J. Jage, P. Laduron, C. Stein, et al. 1991. Group report: strategies for improving the pharmacological approaches to the maintenance of analgesia in chronic pain. In Dahlem Workshop on Towards a New Pharmacotherapy of Pain. Vol. 49. A.I. Basbaum and J.M. Besson, editors. John Wiley \& Sons Ltd. Chichester, UK. 205-226.

2. Cox, B.M. 1991. Molecular and cellular mechanisms in opioid tolerance. In Dahlem Workshop on Towards a New Pharmacotherapy of Pain. Vol 49. A.I. Basbaum and J.M. Besson, editors. John Wiley \& Sons Ltd. Chichester, UK. 137-156.

3. Johnson, S.M., and W.W. Fleming. 1989. Mechanisms of cellular adaptive sensitivity changes: applications to opioid tolerance and dependence. Pharmacol. Rev. 41:435-488.

4. Bousselmame, R., M. Eustache, A. Michael-Titus, and J. Costentin. 1991. Chronic inhibition of enkephalinase induces changes in the antinociceptive and locomotor effects of the enkephalinase inhibitor acetorphan in rats. Neuropharmacology. 30:865-870.

5. Wu, H.H., G.L. Wilcox, and S.C. McLoon. 1994. Implantation of AtT-20 or genetically modified AtT-20/hENK cells in mouse spinal cord induced antinociception and opioid tolerance. J. Neurosci. 14:4806-4814.

6. Miczek, K.A., M.L. Thompson, and L. Shuster. 1982. Opioid-like analgesia in defeated mice. Science (Wash. DC). 215:1520-1522.

7. Terman, G.W., Y. Shavit, J.W. Lewis, J.T. Cannon, and J.C. Liebeskind. 1984. Intrinsic mechanisms of pain inhibition: activation by stress. Science (Wash. DC). 226:1270-1277.

8. Barber, A., and R. Gottschlich. 1992. Opioid agonists and antagonists: an evaluation of their peripheral actions in inflammation. Med. Res. Rev. 12:525562.

9. Stein, C. 1993. Peripheral mechanisms of opioid analgesia. Anesth. Analg. 76:182-191.

10. Stein, C. 1995 . The control of pain in peripheral tissue by opioids. $N$. Engl. J. Med. 332:1685-1690.

11. Stein, C., A.H.S. Hassan, R. Przewlocki, C. Gramsch, K. Peter, and A. Herz. 1990. Opioids from immunocytes interact with receptors on sensory nerves to inhibit nociception in inflammation. Proc. Natl. Acad. Sci. USA. 87: $5935-5939$.

12. Hassan, A.H.S., A. Ableitner, C. Stein, and A. Herz. 1993. Inflammation of the rat paw enhances axonal transport of opioid receptors in the sciatic nerve and increases their density in the inflamed tissue. Neuroscience. 55:185195

13. Przewlocki, R., A.H.S. Hassan, W. Lason, C. Epplen, A. Herz, and C. Stein. 1992. Gene expression and localization of opioid peptides in immune cells of inflamed tissue. Functional role in antinociception. Neuroscience. 48: 491-500.

14. Schäfer, M., L. Carter, and C. Stein. 1994. Interleukin-1 $\beta$ and corticotropin-releasing-factor inhibit pain by releasing opioids from immune cells in inflamed tissue. Proc. Natl. Acad. Sci. USA. 91:4219-4223.

15. Stein, C., A.H.S. Hassan, K. Lehrberger, J. Giefing, and A. Yassouridis 1993. Local analgesic effect of endogenous opioid peptides. Lancet. 342:321324.

16. Stein, C., K. Comisel, E. Haimerl, K. Lehrberger, A. Yassouridis, A Herz, and K. Peter. 1991. Analgesic effect of intraarticular morphine after arthroscopic knee surgery. N. Engl. J. Med. 325:1123-1126.

17. Charlton, E. 1995. Ethical guidelines for pain research in humans. Pain. 63:277-278

18. Chapman, C.R., K.L. Casey, R. Dubner, K.M. Foley, R.H. Gracely, and A.E. Reading. 1985. Pain measurement: an overview. Pain. 22:1-31

19. Stein, C., and G. Mendl. 1988. The german counterpart to McGill pain questionnaire. Pain. 32:251-255.

20. Stein, C., C. Gramsch, and A. Herz. 1990. Intrinsic mechanisms of antinociception in inflammation. Local opioid receptors and $\beta$-endorphin. $J$. Neurosci. 10:1292-1298.

21. Zar, J.H. 1984. Biostatistical Analysis. Prentice-Hall, Englewood Cliffs, NJ.

22. Melzack, R. 1975. The McGill pain questionnaire: major properties and scoring methods. Pain. 1:277-299.

23. Puttfarcken, P.S., L.L. Werling, and B.M. Cox. 1988. Effects of chronic morphine exposure on opioid inhibition of adenylyl cyclase in $7315 \mathrm{c}$ cell membranes: a useful model for the study of tolerance at $\mu$ opioid receptors. Mol. Pharmacol. 33:520-527.

24. Werling, L.L., P.N. McMahon, and B.M. Cox. 1989. Selective changes in $\mu$ opioid receptor properties induced by chronic morphine exposure. Proc. Natl. Acad. Sci. USA. 86:6393-6397.

25. Attali, B., and Z. Vogel. 1989. Long-term opiate exposure leads to reduction of the $\alpha \mathrm{i}-1$ subunit of GTP-binding proteins. J. Neurochem. 53:16361639.

26. Griffin, M.T., P.Y. Law, and H.H. Loh. 1985. Involvement of both inhibitory and stimulatory guanine nucleotide binding proteins in the expression of chronic opiate regulation of adenylate cyclase activity in NG108-15 cells. $J$. Neurochem. 45:1585-1589.

27. Sharma, S.K., W.A. Klee, and M. Nirenberg. 1975. Dual regulation of adenylate cyclase accounts for narcotic dependence and tolerance. Proc. Natl. Acad. Sci. USA. 72:3092-3096.

28. Duman, R.S., J.F. Tallman, and E.J. Nestler. 1988. Acute and chronic opiate-regulation of adenylate cyclase in brain: specific effects in locus coeruleus. J. Pharmacol. Exp. Ther. 246:1033-1039.

29. Jeanjean, A.P., J.-M. Maloteaux, and P.M. Laduron. 1994. IL-1ß-like Freund's adjuvant enhances axonal transport of opiate receptors in sensory neurons. Neurosci. Lett. 177:75-78.

30. Schäfer, M., Y. Imai, G.R. Uhl, and C. Stein. 1995. Inflammation enhances peripheral $\mu$-opioid receptor-mediated analgesia, but not $\mu$-opioid receptor transcription in dorsal root ganglia. Eur. J. Pharmacol. 279:165-169.

31. Rasenick, M.M., and S.R. Childers. 1989. Modification of $\mathrm{G}_{\mathrm{s}}$-stimulated adenylate cyclase in brain membranes by low $\mathrm{pH}$ pretreatment: correlation with altered guanine nucleotide exchange. J. Neurochem. 53:219-225.

32. Selley, D.E., C.S. Breivogel, and S.R. Childers. 1993. Modification of G protein-coupled functions by low $\mathrm{pH}$ pretreatment of membranes from NG108- 
15 cells: increase in opioid agonist efficacy by decreased inactivation of G proteins. Mol. Pharmacol. 44:731-741.

33. Lee, N.M. 1995. Dynorphin A: a rectifying peptide. In Discovery of Novel Opioid Medications. Vol. 147. R.S. Rapaka and H. Sorer, editors. National Institute on Drug Abuse. Rockville, MD 161-169.

34. Millan, M.J. 1993. Multiple opioid systems and chronic pain. In Opioids
II. Vol. 104/II. A. Herz, editor. Springer-Verlag. Berlin/Heidelberg. 128-162. 35. Morris, B.J. 1993. Control of receptor sensitivity at the mRNA level. Mol. Neurobiol. 7:189-205.

36. Antonijevic, I., S.A. Mousa, M. Schäfer, and C. Stein. 1995. Perineurial defect and peripheral opioid analgesia in inflammation. J. Neurosci. 15:165-172. 